\title{
CONSTANTINE VII PORPHYROGENNETOS ON CROATS IN EARLY MEDIEVAL SOUTHERN PANNONIA (DAI, c. 30, 75-78): A NOTE ON CONCEPT AND METHOD OF BYZANTINE HISTORY WRITING ${ }^{1}$
}

\author{
Hrvoje Gračanin \\ University of Zagreb, Zagreb, Croatia
}

\begin{abstract}
The paper endeavours to discuss anew a scholarly puzzle related to the Croatian early Middle Ages and centred on a few lines from Constantine VII Porphyrogennetos's De administrando imperio, which in English translation are as follows: And of the Croats who arrived to Dalmatia one part separated and ruled Illyricum and Pannonia. And they also had an independent ruler who was sending envoys, though only to the ruler of Croatia from friendship. Taking a different approach from the complete dismissal of the two sentences as a pure fiction or a mere literary device, the paper instead attempts to trace the concept behind this account as well as its underlying meaning. On the one hand, it seeks to detect the methods or strategies used by the royal compiler in trying to elucidate the past. On the other hand, it aims to provide a thorough historical analysis and offer a possible interpretation in opposition to the view, still largely extant in the Croatian scholarship, that this account is an evidence for an early presence of the group called Croats in southern Pannonia.

Key words: De administrando imperio, Croats, southern Pannonia, source analysis, migrations, early medieval identity and ethnicity.

Citation. Gračanin H. Constantine VII Porphyrogennetos on Croats in Early Medieval Southern Pannonia (DAI, c. 30, 75-78): A Note on Concept and Method of Byzantine History Writing. Vestnik Volgogradskogo gosudarstvennogo universiteta. Seriya 4. Istoriya. Regionovedenie. Mezhdunarodnye otnosheniya [Science Journal of Volgograd State University. History. Area Studies. International Relations], 2020, vol. 25, no. 6, pp. 24-43. DOI: https://doi.org/10.15688/jvolsu4.2020.6.2
\end{abstract}

УДК 94(4)“04/14”:930.1

Дата поступления статьи: 24.07.2020

ББК 63.3(4)41-9Г

Дата принятия статьи: 25.09.2020

\section{КОНСТАНТИН VІІ БАГРЯНОРОДНЫЙ О ХОРВАТАХ \\ В РАННЕСРЕДНЕВЕКОВОЙ ЮЖНОЙ ПАННОНИИ (DAI, c. 30, 75-78): \\ ЗАМЕЧАНИЯ О КОНЦЕПЦИИ И МЕТОДЕ ВИЗАНТИЙСКОЙ ИСТОРИОГРАФИИ ${ }^{1}$}

\author{
Хрвое Грачанин \\ Загребский университет, г. Загреб, Хорватия
}

\begin{abstract}
Аннотация. В статье предпринята новая попытка обсудить научную головоломку, имеющую отношение к раннесредневековой хорватской истории и сосредоточенную в нескольких строчках трактата «Об управлении империей» Константина Багрянородного, которые в переводе на русский язык звучат следующим образом: «И от থे хорватов, которые пришли в Далмацию, одна часть отделилась и правила Иллириком и Паннонией. И они также имели независимого правителя, который отправлял послов, однако только к правителю Хорватии ради дружбы». 寻 Применяя иной подход, нежели тот, что заключается в полном отклонении двух предложений как чистой выдумки или художественного приема, автор вместо этого пытается проследить концепцию, лежащую в основе данного рассказа, а также его скрытый смысл. С одной стороны, он стремится выявить методы и стратегии, использованные царственным составителем трактата в попытке прояснить прошлое. С другой стороны, цель работы - прове-
\end{abstract}


сти тщательный исторический анализ и предложить возможную интерпретацию в противовес точке зрения, все еще широко распространенной в хорватской науке, что это сообщение является доказательством раннего присутствия группы, называемой хорватами, в Южной Паннонии.

Ключевые слова: «Об управлении империей», хорваты, Южная Паннония, источниковедческий анализ, миграция, раннесредневековая идентичность и этническая принадлежность.

Цитирование. Грачанин X. Константин VII Багрянородный о хорватах в раннесредневековой Южной Паннонии $(D A I$, c. 30, 75-78): замечания о концепции и методе византийской историографии // Вестник Волгоградского государственного университета. Серия 4, История. Регионоведение. Международные отношения. -2020. - Т. 25, № 6. - С. 24-43. - (На англ. яз.). - DOI: https://doi.org/10.15688/jvolsu4.2020.6.2

Introduction. The Croatian early Middle Ages is in many aspects just a collection of research puzzles, a mosaic of various details that open more questions than they give answers. As it stands today, one can easily say that the entire early medieval Croatian history is a construct which makes it only possible to follow the historical processes in broad outlines since the literary and material sources available to scholars mostly offer the material for merely making general, more or less founded, assumptions (cf. remarks in [29, p. 248]). An example of such a scholarly puzzle, which comparably engages both Croatian historians and archaeologists, relates to a question of the early medieval presence of the Croat ethnie in southern Pannonia, i.e. modern Northern Croatia or, as it also called, the region between the rivers Sava, Drava and Danube.

Research problems and approaches. In a nutshell, the entire problem is centred, which is not a rarity when it comes to the history of the Croatian early Middle Ages, on an isolated record. In this case, it is the two lines from the famous treatise composed by the Byzantine emperor Constantine VII Porphyrogennetos (905-959) for his son and heir Romanus II, and known under the Latin historiographic title De administrando imperio, commonly abbreviated as the $D A I$, and,

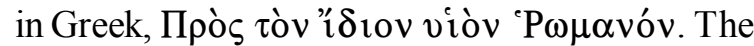
work is, in essence, a sort of a Byzantine Fürstenspiegel, a manual with guidelines and useful facts primarily for diplomatic purposes, which emphasized the importance of proper information or, at least, helpful tips as such knowledge would give obvious advantages in dealings with foreign states and peoples ${ }^{2}$. Not that the royal compiler was always able to adequately fulfill the task taken upon himself, since the collecting and arranging of the material proved to be, in some instances, too challenging and some information is clearly garbled ${ }^{3}$.
Nevertheless, even though the final product - in its present form - clearly lacks a precise editing and finishing touches, it was a project that fitted well into Constantine Porphyrogennetos's overall literary program (whether or not he was its actual instigator), and it was sufficiently sophisticated in the sense that it had an elaborated agenda and general structure, and aimed at offering new perspectives on the up to four century long past as well as recent past of the regions and polities (with conspicuous omissions, at least to a modern researcher's eyes) relevant or of value to current Byzantine interests. That is to say, whatever one may think of how successful was Constantine Porphyrogennetos in his undertaking, the fact remains that the $D A I$ was an attempt at understanding and explaining the geopolitical situation of the day in its historical perspective, and finding practical lessons with bearing on the challenges that the existing circumstances posed. Therefore, it may be contended that the $D A I$ was perhaps the most complex of the Constantinian collections considering its goals and implications ${ }^{4}$. In other words, notwithstanding its apparent haphazardness, the $D A I$ seems to be a deliberate document containing purposely collected pieces of information with concrete meanings and intents. Hence - I shall venture to claim - if one manages to decipher the background, the nature and the context of these pieces of information, they might perhaps be able to unlock their actual meaning and specific ramifications.

In line with that, the following examination will depart from the approach that, at first look, might seem innovative, mirroring recent theoretical advances and devoid of any ulterior motives but, by its dismissal of historical phenomena, processes or events in the manner they are portrayed in the DAI as Constantine Porphyrogennetos's fabrications and inventions 
resulting from narrative strategies, instead of considering and addressing them in their own right with adducing all the possible evidence, does not get us actually closer to understanding Constantine's concepts and methods nor it contributes to the interpretative clarification of not easily explainable claims or pieces of information or textual places ${ }^{5}$. The main research problem tackled here is whether the Croats or, better yet, the fundamental (eponym) ethnic group or groups, which participated decisively in the construction of Croat ethnic identity ${ }^{6}$, already settled in south Pannonian area in the seventh century A.D., or this, in all its value, cannot be the case, that is to say, the presence of the Croat ethnie in the region between the rivers Sava, Drava and Danube in the early Middle Ages should rather be seen as a result of insufficiently founded conjectures of modern scholars based on not enough informed claim by the source. The paper will argue that the view supporting such an early presence of the Croats in southern Pannonia is misleading, and if there were any Croat name-bearing groups in that region at all - which cannot be entirely excluded nor corroborated - their number must have been negligible when compared to other Slav(icized) populations, which is also very much consistent with the circumstance that the area of the primary construction of Croat identity was much farther to the south, close to the Adriatic ${ }^{7}$.

Presenting the source's account. The two sentences narrating about the Croats migrating from Dalmatia to Illyricum and Pannonia are found in the Chapter 30 of the DAI, entitled The narrative about the theme Dalmatia, and in English translation they are as follows: And of the Croats who arrived to Dalmatia one part separated and ruled Illyricum and Pannonia. And they also had an independent ruler who was sending envoys, though only to the ruler of Croatia from friendship ('A $\pi$ ò $\delta \grave{\varepsilon} \tau \hat{\omega} v$

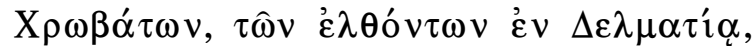

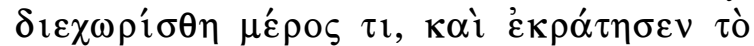

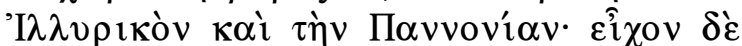

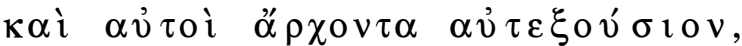

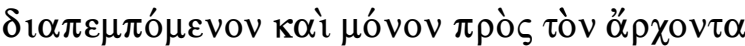
$\mathrm{X} \omega \omega \beta \alpha \tau^{\prime} \alpha_{\alpha} \kappa \alpha \tau \dot{\alpha} \varphi \imath \lambda^{\prime} i \alpha v ; D A I$, c. 30, 75-78) ${ }^{8}$.

This passage is preceded in the DAI by the story about the Croat's arrival to Dalmatia from their ancestral land, their fight against and victory over the Avars, and their occupation of Dalmatia, as well as by the remark about the Croat's ancestral land near Saxony (and beyond Bavaria), where they are subordinate ( $(\tau o$ ó $\kappa \varepsilon \imath \tau \alpha \imath$ ) to Franks and in friendly relationship with the Turks (i.e. Magyars), and is followed by the story about how, in Dalmatia, the Croats were also subject ( $i \pi \varepsilon \tau \alpha \dot{\sigma} \sigma \sigma o v \tau o$ ) to Franks, but then rose against them because of their brutal reign, prevailed over them and became sovereign and autonomous

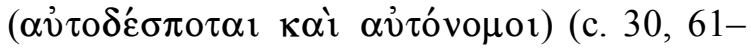
$75,78-88)^{9}$.

The context in which the two relevant sentences appear is tightly related to a sort of setting of, in modern terms, a geopolitical stage of East-Central Europe from the Byzantine imperial perspective, where the Croats are given a prominent place as a gens that possesses three separate regions (one is Dalmatia, the other is Illyricum and Pannonia, and the third is their ancestral land), of which the two they control were of an immediate interest to Byzantines. The mechanism by which the Croats are said to have gotten into position to possess these two regions is migration, which, as the source tells us, was twofold and happening at two different times: the Croats first came to Dalmatia and conquered the Avars, and afterwards a part of them detached from the main group and crossed to Illyricum and Pannonia, where they established a separate polity (an archontry, in Byzantine phrasing), same as there was a Croat polity in Dalmatia, which is said to have been subject to Franks for an unspecified amount of time (how and when it came under the Frankish dominion is never explicitly explained), before it became sovereign and autonomous (again). The ruler of the Croats of Illyricum and Pannonia is also accorded an

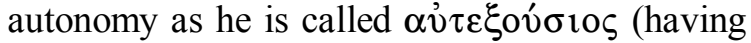
self-authority) and portrayed as possessing right to send envoys, but his status is never described as fully authoritative as that of the prince of the Croats of Dalmatia ${ }^{10}$. Furthermore, since the claim about the Croats of Illyricum and Pannonia having an independent ruler is in the past tense (even though the verb's imperfective aspect is indicative of duration (cf. [88, p. 95])), it may be surmised that, from Constantine's perspective, this was something occuring in the past and no longer extant in his days. What may be further concluded from the order of storytelling is that the Croats of Dalmatia fell under the Frankish control after the 
establishment of the Croat polity in Illyricum and Pannonia, but that the cordial relations between the two polities continued.

The Croats as being in Pannonia are also alluded to in Constantine's biography of his grandfather Basil I [15, c. 52, 6-11, pp. 188-189]: "Moreover, Scythians dwelling in Pannonia, Dalmatia and beyond - I mean the Croats, Serbs, Zachlumians, Terbuniotes, Kanalites (i.e. Konavlians), Diocletians (i.e. Docleans) and Rentanians (i.e. Neretvians) - rebelled against the immemorial dominance of the Romans, and became independent and sovereign, led only by

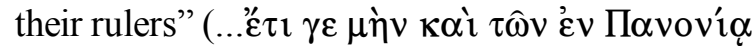

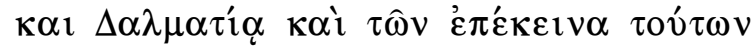

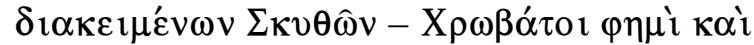

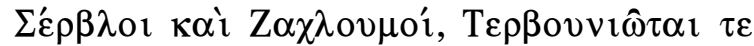

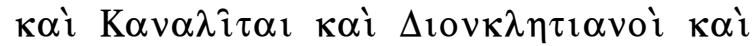

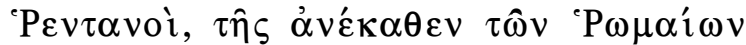

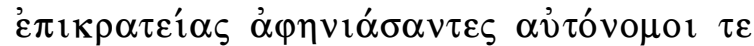

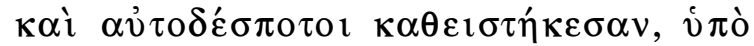

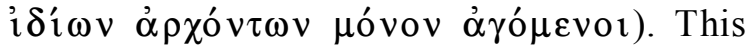
development was dated by Constantine to the reign of emperor Michael II (820-829) [15, c. 52, 1-3, pp. 188-189] ${ }^{11}$. It is important to point out that this passage has a parallel in the DAI (c. 29, 6366), where, however, there is no mention of Pannonia.

Variety of hypotheses ${ }^{12}$. The older Croatian scholarship - taking the account in the $D A I$ at face value - saw the two sentences as a confirmation that the Croats were present in the region between the rivers Sava, Drava and Danube since their (assumed) arrival in the seventh century. Such a view was supported, among others, by Šime Ljubić [61, p. 117] and Tadija Smičiklas [84, pp. 108-109, 160-161], and it had already been maintained by the so-called father of the Croatian historiography Ioannes Lucius (Giovanni Lucio, Ivan Lučić) in his capital work The Kingdom of Dalmatia and Croatia (De regno Dalmatiae et Croatiae) [63, lib. I, c. $12,21-34$, p. 306], and repeated by Daniele Farlati in the second volume of his monumental work The Sacred Illyricum (Illyricum Sacrum) [25, Th. III, c. $3, \S 2$, p. 312]. The identical standpoint was adopted by Vjekoslav Klaić [54, p. 42], Josip Bösendorfer [10, p. 62], and, eventually, by the founding figure of the modern Croatian historiography Ferdo Šišić [79, p. 277]. The same opinion was also held by Kaspar Zeuss
[92, p. 612], Pavel Jozef Šafárik (Paul Joseph Schaffarik) [76, pp. 278-279], Hermann L. Krause [57, p. 4], Ernst Dümmler [20, pp. 373374], John Bagnell Bury [13, p. 275], Stanko Guldescu [42, pp. 92ff.], František (Francis) Dvornik [50, pp. 118-119, 121], John Van Antwerp Fine, Jr. [29, pp. 254ff. ${ }^{13}$ ], and Huw M. A. Evans [24, pp. 106, 270]. It has echoed strongly in part of the contemporary Croatian scholarship, especially in the works by Ivo Goldstein [32, pp. 9, 94; 33, pp. 220-221], and has been particulary insisted upon by Vladimir Sokol who has even assumed that the Croatian ethnie might have been present in the area north of the Drava, around the lake Balaton in modern Hungary [85, p. 194; 68, pp. 17-18]. Hence it has become a rule to speak of "Pannonian Croats", and "Pannonian Croatia" or "Posavian Croatia" (the latter took its historiographic name after the river Sava), and the rulers (the duces of the Frankish sources) associated with the region between the rivers Sava, Drava and Danube (Liudewit, Ratimar, Brazlavo ${ }^{14}$ ) have all been made into ethnic Croats. Moreover, as voiced by some scholars, even the Slav population(s) living in today's Croatian Baranya in the tenth and eleventh centuries were Croat [75, p. 104].

Some researchers have pointed out that the presence of Croats in Pannonia does not necessarily have anything to do with the Croat migration in the seventh century, and formulated a hypothesis that the sentences actually describe the situation in the age of the Croat king Tomislav (first half of the tenth century) [39, pp. 30, 31; 52, p. $278^{15}$ ]. However, there were opinions that the information about the independent Croat prince in Pannonia could only refer to the times before Tomislav [26, pp. 74-75], although some scholars raised objection that, chronologically, this would have been too early [53, p. 52].

There have also been conjectures about the existence of the autonomous Croat principality in southern Pannonia, the so-called "Pannonian Croatia", in the early ninth century $[64$, p. $56 ; 67$, p. 61], or that the rule of the Croat prince extended, after the suppression of Liudewit's rebellion, into the region between the rivers Sava, Drava and Danube in the first half of the ninth century $[3$, p. $90 ; 12$, p. 400]. On the other hand, some concluded that there is no evidence that there had ever been a unified Croat dominion 
encompassing both Slavonia and Dalmatia, and opted for an independent principality in Slavonia in the tenth century [32, pp. 284-285; 33, p. $\left.231^{16}\right]$.

The cause for an equally fertile scholarly dispute was the area which is meant under Constantine Porphyrogennetos's Illyricum and Pannonia. Thus, Ioannes Lucius had already believed Illyricum to be the interior of Dalmatia, and that Pannonia was Pannonia Savia, the late Roman province encompassing the western parts of the region between the rivers Sava, Drava and Danube. Some scholars assumed that Illyricum and Pannonia refer, respectively, to Bosnia and the entire region between the rivers Sava, Drava and Danube [61, p. 117], or that a part of northwestern Bosnia was meant under Illyricum [67, pp. 61, 84], or even the entire area between Dalmatinska Zagora (the mountainous region behind the coastal strip of Dalmatia) and modern Slavonia [66, p. 164]. This was decisively rejected by others, who even sought to introduce designations that are not corroborated in the sources, such as "the Illyrian Panonnia", which, in their view, would encompass the area of the so-called "Greater Pannonia" along the edge of Illyricum or southern Pannonia, i.e. the region between the rivers Sava, Drava and Danube [88, p. $93 ; 53$, pp. 40-42]. Others yet thought that both Illyricum and Pannonia refer exclusively to the region between the rivers Sava and Drava [57, p. 4; 39, p. $31 ; 26$, p. $74 ; 12$, p. 398]. Moreover, one scholar proposed that Constantine Porphyrogennetos's Pannonia should be placed around the lake Balaton in modern Hungary, but this was refuted as unsubstantiated [41, pp. 93-95; contra 40, pp. 173176]. Some believed that either Noricum or Doclea (Duklja) were meant under Illyricum ${ }^{17}$. Yet another scholar thought that Pannonia refers to the area between the lower Sava and the Danube (modern Syrmia), and Illyricum to the territory encompassing Dalmatia up to the Sava in the north and the Drina in the east [20, pp. 373-374].

Posing the research questions. The variety of opinions just surveyed clearly shows quite a perplex scholarly problem as the source's succinctness only raises a number of possible interpretations, some of which are more or less probable, and some straight out unacceptable. In approaching the analysis of the source material one has to first determine if it is at all reliable before proceeding to decipher and interpret its actual meaning. For a long time, there had been a tacit opinion among the scholars that the account is not to be suspected, i.e. that it is based on a true tradition. More recently, however, there has been a tendency to treat the historical literary sources as mere narratives, stories that create events or even invent the reality based on literary techniques and literary topoi, thus taking away their power of evidence altogether. To be sure, it is important to bear in mind that the textual sources are multilayered and multifaceted products of specific periods of time, sociopolitical, ideological and cultural contexts, goals, experiences and opinions of the authors, and views, interests and needs of the targeted audiences, meaning that the information they offer cannot be trusted at face value and simply fitted into a reconstruction that seems most likely to a researcher ${ }^{18}$. While fully taking this into account, the approach taken here is not to reject possible historicity of what was meant by the two sentences under scrutiny, but to try to go behind this particular representation of the past by avoiding pitfalls of postmodernist and poststructuralist hypercriticism. Therefore, the following analysis is conducted under the assumption of, mutatis mutandis, basic trustworthiness and usefulness of the $D A I$ as an historical source, not the least as a testimony of how the past was perceived. After all, had Constantine Porphyrogennetos composed his treatise by knowingly and intentionally introducing the literary creations in his text in an attempt to be seen as following the established tradition of Greek historiography and ethnography, the treatise would have lost its practical and instructive - that is to say, its principal - purpose (however much imbued with ideology and Constantine's own perceptions and rationalizations).

This brings us to the question of the account's actual meaning. As it seems, the real background to what it describes is not clear on several different levels. Who were the Croats of Illyricum and Pannonia? In what sense did they separate from the Croats of Dalmatia? When might this have happened if at all? What do Illyricum and Pannonia refer to? What was this independent Croat principality? How are we to understand the claim about cordial relations between the two Croat princes? Before taking up an historical analysis and proposing answers to the questions as laid out, we shall investigate three separate issues that might prove valuable for better 
understanding of Constantine Porphyrogennetos's approaches in explaining the past.

Movements of peoples and groups in the DAI. Up until recently the idea of Croat migration as an historical fact established by the DAI has never been challenged. Lately, a number of sharp observations has been made aimed at dismantling of the migration narrative [16, pp. 138-139; 17 , pp. $41 \mathrm{ff}$; 18, pp. 116ff.; 22, pp. 112ff.; 23, pp. 158ff.; 9, pp. 210ff.; with 2, p. 148; 1, p. 190]. Therefore, it seems worthwhile to examine how the appearance of peoples or groups in some region or their shift to another area is depicted in the DAI. These movements may tentatively be divided into several categories based on their character as presented in the DAI: conquest; branching-off; refuge seeking; unsanctioned settlement; sanctioned settlement; resettlement by invitation; planned resettlement; forced resettlement; divinely inspired migration; seasonal movements (Table 1).

\section{Table 1. Movements of peoples and groups in the DAI}

\begin{tabular}{|c|c|}
\hline Conquest & Branching-off \\
\hline $\begin{array}{l}\text { c. } 25,23-24,40-41: \text { the Visigoths, after taking Rome, } \\
\text { conquered the Gallic provinces and later Spain as well }\end{array}$ & \multirow{2}{*}{$\begin{array}{l}\text { c. } 30,61-67 \text { : at this time (i.e. when the Avars conquered } \\
\text { Dalmatia), the Croats lived beyond Bavaria, and a family } \\
\text { of five brothers and two sisters separated from them, } \\
\text { arrived with their folk in Dalmatia, which was possessed } \\
\text { by Avars } \\
\text { c. } 31,3-6 \text { : the Croats who are now settled in Dalmatia are } \\
\text { descended from the Croats who are settled beyond } \\
\text { Turkey and next to Francia }\end{array}$} \\
\hline $\begin{array}{l}\text { c. } 29,14-22,36-49 \text { : the Slavs, also called Avars, were } \\
\text { incited by a plundering incursion made by the Dalmatian } \\
\text { Romans across the Danube to cross the river, took Salona } \\
\text { by a strategem, settled down in Dalmatia and gradually } \\
\text { conquered the places of the Romans } \\
\text { c. } 30,18-61 \text { : the Avars conquered all the country of } \\
\text { Dalmatia and settled down in it }\end{array}$ & \\
\hline \multirow{2}{*}{$\begin{array}{l}\text { c. 37, 2-14: the Pechenegs used to be settled on the rivers } \\
\text { Atil (i.e. Volga) and Geich (i.e. Ural), but then were } \\
\text { expelled from their country. After they had fled and } \\
\text { wandered around in search of where to settle down, they } \\
\text { arrived to the country where the Turks dwelt. After a } \\
\text { battle they cast the Turks out and expelled them, and } \\
\text { settled down in their country }\end{array}$} & $\begin{array}{l}\text { c. } 30,75-77: \text { of the Croats who arrived to Dalmatia one } \\
\text { part separated and ruled Illyricum and Pannonia }\end{array}$ \\
\hline & $\begin{array}{l}\text { c. } 32,3-7: \text { the Serbs are descended from the Serbs who } \\
\text { are settled beyond Turkey and are neighbors to Francia, } \\
\text { and this is where they originally lived }\end{array}$ \\
\hline \multirow{8}{*}{$\begin{array}{l}\text { c. } 38,55-60 ; \text { c. } 40,16-27 \text { : after the Pechenegs fell upon } \\
\text { the Turks (for the second time) and expelled them, the } \\
\text { Turks were on a search for a land to settle in, and they } \\
\text { expelled those who dwelt in Great Moravia and settled } \\
\text { down in their land, where they live to this day }\end{array}$} & $\begin{array}{l}\text { c. } 32,16-18: \text { one part of the Thessalonican Serbs decided to } \\
\text { depart to their own homes and were sent off by the emperor }\end{array}$ \\
\hline & $\begin{array}{l}\text { c. } 33,8-10: \text { the Zachlumians are Serbs from the time of } \\
\text { that prince who came in refuge to the emperor Heraclius }\end{array}$ \\
\hline & $\begin{array}{l}\text { c. } 33,16-18: \text { the family of the prince of Zachlumians, } \\
\text { Michael, came from those who live on the river Visla }\end{array}$ \\
\hline & $\begin{array}{l}\text { c. } 34,3-6: \text { the Terbuniotes and Kanalites are descended } \\
\text { from the unbaptized Serbs, from the time of that prince } \\
\text { who came from the unbaptized Serbia and in refuge to the } \\
\text { emperor Heraclius }\end{array}$ \\
\hline & $\begin{array}{l}\text { c. } 35,1-9 \text { : the land where the Diocletians now dwell was } \\
\text { populated in the time of the emperor Heraclius, just as } \\
\text { were Croatia, Serbia, Zachlumia, Terbounia and the } \\
\text { country of Kanalites }\end{array}$ \\
\hline & $\begin{array}{l}\text { c. } 36,5-9 \text { : the Pagani (also called Arentanians) are descended } \\
\text { from the unbaptized Serbs, of the time of that prince who } \\
\text { came in refuge to the emperor Heraclius, and their country } \\
\text { was populated in the time of the emperor Heraclius }\end{array}$ \\
\hline & $\begin{array}{l}\text { c. } 37,50-53: \text { one part of the Pechenegs, at the time they } \\
\text { were expelled from their country, remained and united with } \\
\text { the Uzes, and they are among the Uzes even to this day }\end{array}$ \\
\hline & $\begin{array}{l}\text { c. } 38,24-31: \text { after the Turks were defeated by the } \\
\text { Pechenegs (for the first time), they split in two parts, one } \\
\text { part settled in Persia, while the other settled in the } \\
\text { western region, where now the Pechenegs live }\end{array}$ \\
\hline
\end{tabular}




\begin{tabular}{|c|c|}
\hline $\begin{array}{l}\text { Refuge seeking } \\
\end{array}$ & \begin{tabular}{|l} 
Sanctioned settlement \\
\end{tabular} \\
\hline $\begin{array}{l}\text { c. } 31,8-10,26-27: \text { the Croats came in refuge to the } \\
\text { emperor Heraclius before the Serbs did the same; the } \\
\text { land, in which the Croats had settled, was originally under } \\
\text { the authority of the Roman emperor }\end{array}$ & $\begin{array}{l}\text { c. } 25,25-29: \text { the Goths were allowed to dwell in Thrace, } \\
\text { and then were permitted to conquer the Western Empire } \\
\text { (i.e. Italy) }\end{array}$ \\
\hline $\begin{array}{l}\text { c. } 32,7-10 \text { : one of the two brothers who succeeded the } \\
\text { reign over White Serbia took one half of the folk and } \\
\text { came in refuge to the emperor Heraclius }\end{array}$ & $\begin{array}{l}\text { c. } 32,10-11: \text { the Serbs who came in refuge to the } \\
\text { emperor Heraclius were granted the province of } \\
\text { Thessalonica to settle in }\end{array}$ \\
\hline $\begin{array}{l}\text { c. } 41,20-25: \text { the country of the Moravians was destroyed } \\
\text { and conquered by the Turks who even presently dwell in } \\
\text { it, while the Moravians were scattered and fled for refuge } \\
\text { to the Bulgars, Turks, Croats and the rest of the nations }\end{array}$ & $\begin{array}{l}\text { c. } 32,18-27 \text { : the Thessalonican Serbs who left the } \\
\text { province of Thessalonica on a return migration were } \\
\text { granted by the emperor Heraclius other land to settle in } \\
\text { and settled down in what is now Serbia, Pagania, the } \\
\text { country of Zachlumians, Terbounia, and the country of } \\
\text { Kanalites }\end{array}$ \\
\hline $\begin{array}{l}\text { Unsanctioned settlement } \\
\end{array}$ & Resettlement by invitation \\
\hline $\begin{array}{l}\text { c. } 25,15-21: \text { the Goths, Visigoths, Gepids and Vandals, } \\
\text { who were settled in the regions across the Danube, } \\
\text { crossed the river and settled on the Roman soil }\end{array}$ & $\begin{array}{l}\text { c. } 25,32-49: \text { the Vandals were persuaded by the Roman } \\
\text { general in Africa, Boniface, to cross the sea strait and } \\
\text { settle in Lybia }\end{array}$ \\
\hline c. 25, 24-25: the Goths first held Pannonia & c. $27,32-37$ : at the time the Lombards lived in Pannonia, \\
\hline $\begin{array}{l}\text { c. 25, 29-32: the Vandals joined with the Alans and } \\
\text { Germans (i.e. Franks), crossed the river (Rhine) and } \\
\text { settled in Spain }\end{array}$ & $\begin{array}{l}\text { where the Turks presently dwell (c. } 27,30-31) \text {, they were } \\
\text { invited by the patrician Narses to come to Italy and settle } \\
\text { in it, and so they took their families and arrived in } \\
\text { Beneventum }\end{array}$ \\
\hline $\begin{array}{l}\text { Planned resettlement } \\
\end{array}$ & \begin{tabular}{|l} 
Forced resettlement \\
\end{tabular} \\
\hline $\begin{array}{l}\text { c. } 29,1-5 ; 33,3-5 ; 35,3-5 ; 36,3-5: \text { the emperor } \\
\text { Diocletian brought families from Rome and settled the } \\
\text { Romans in Dalmatia }\end{array}$ & $\begin{array}{l}\text { c. 28, 4-16 (cf. c. 27, 71-75): those who are now called } \\
\text { Venetians were Franks from Aquileia and from other } \\
\text { places in Francia, and they lived on the mainland opposite } \\
\text { Venice. But after Attila, king of the Avars, devastated and } \\
\text { depopulated all the parts of Francia, the Franks from } \\
\text { Aquileia and other cities of Francia began to flee and to } \\
\text { come to the inhabited islands, and after the king Attila } \\
\text { advanced as far as Rome and Calabria leaving Venice } \\
\text { behind, those who fled to the islands decided to settle } \\
\text { there and they have been settled there to this day }\end{array}$ \\
\hline $\begin{array}{l}\text { c. 47, 15-25: the emperor Justinian II decided to populate } \\
\text { Cyprus, persuaded the caliph to dismiss the folk of } \\
\text { Cyprus that were in Syria, and resettled those who lived } \\
\text { in other parts of the empire }\end{array}$ & $\begin{array}{l}\text { c. 29, 49-50: after the Slavs/Avars' conquest the } \\
\text { remaining Dalmatian Romans saved themselves in coastal } \\
\text { cities } \\
\text { c. } 29,230-235: \text { there was a migration of a group of } \\
\text { people from Salona to Rausium }\end{array}$ \\
\hline \multirow{2}{*}{$\begin{array}{l}\text { c. } 32,135-142 \text { : the Serbs who were staying in Croatia, } \\
\text { Bulgaria and the rest of the countries came back to } \\
\text { Serbia, and those who escaped from Bulgaria to } \\
\text { Constantinople were sent back by the emperor to Serbia }\end{array}$} & $\begin{array}{l}\text { c. } 39,2-7 ; 40: 6-7: \text { the Kabaroi, who were of the race of } \\
\text { Chazars, were forced to escape and came and settled with } \\
\text { the Turks in the land of the Pechenegs }\end{array}$ \\
\hline & $\begin{array}{l}\text { c. } 32,123-126 \text { : the Bulgars entered Serbia and took away } \\
\text { with them the entire folk and carried them into Bulgaria, } \\
\text { though a few escaped away and entered Croatia }\end{array}$ \\
\hline $\begin{array}{c}\text { Divinely inspired migration } \\
\end{array}$ & Seasonal movements \\
\hline \multirow{3}{*}{$\begin{array}{l}\text { c. } 45,10-12,38-39: \text { the Iberians originate from } \\
\text { Jerusalem, and were warned by an oracular dream to } \\
\text { migrate from there and settle near Persia, in the country } \\
\text { where they now dwell }\end{array}$} & $\begin{array}{l}\text { c. 8, 34-35: the Pechenegs cross the river Dnieper to } \\
\text { spend summer on its far side }\end{array}$ \\
\hline & $\begin{array}{l}\text { c. } 9,105-111: \text { at the beginning of winter, the Kievan } \\
\text { Russians go off to other Slav regions of their tributaries } \\
\text { and come back to Kiev in spring }\end{array}$ \\
\hline & $\begin{array}{l}\text { c. } 11,6-8 \text { : along their routes, the Chazars pass through to } \\
\text { Sarkel }\end{array}$ \\
\hline
\end{tabular}

Of particular interest here is the manner in which the $D A I$ explains the appearance of the new groups after the arrival of Croats and Serbs, namely, the Zachlumians, Terbuniotes, Kanalites, Diocletians and Pagani (Arentanians). The Serbs are said to have been allowed to settle by the emperor Heraclius in what is now Serbia, Pagania, the country of Zachlumians, Terbounia, and the country of Kanalites, which is then further corroborated by a statement that some are Serbs 
(Zachlumians), while others (Terbuniotes, Kanalites, Pagani/Arentanians) are descended from Serb's from the time of the Serbs arrival from their ancestral land. This would posit that the Serbs split off in several additional groups at a very early stage. The only excluded are the Diocletians, even though their land is said to have been populated in the time of the emperor Heraclius as well ${ }^{19}$. The key to understand Constantine Porphyrogennetos's logic behind these claims of branching-off, i.e. connecting what were obviously diverse identity groups under one ethnic umbrella label, seems to be his limiting of the duration of the Terbouniotes' and Kanalites' being descended from the Serbs: until the prince of Serbia, Blastimer, made the zupan of Trebounia independent (c. 34, 6-10). That is to say, Constantine equated the ethnic identity affiliation with the political overlordship. He seems to have followed the same "misconception" when he turned the Venetians into Franks (c. 28, 4-6). The DAI provides additional hints to such an interpretation: Pagania is indicated to have been subject to the prince of Serbia in the early tenth century (c. 32, 84-85), and the princes of Trebounia are said to have been always under the command of the prince of Serbia (c. 34, 11-12).

What also merits attention is the claim by some scholars that what separates all the migration stories in the DAI from the story of Croat (as well as of Serb) migration is that Constantine Porphyrogennetos did not provide any reason for their movement ${ }^{20}$. That is not entirely valid observations since the $D A I$ does not provide any reasons for initial movements of the Goths, Visigoths, Gepids and Vandals as well, the story of which was copied from the Chronographia of Theophanes Confessor [89, A.M. 5931, pp. 93 95], who, in turn, excerpted Prokopios of Caesarea's Wars [74, lib. 3, c. 2-3, pp. 311-324; lib. 5, c. 1, pp. 4-10], where much more detail is given. Furthermore, the Croats are also depicted as seeking refuge, albeit the details as to the reasons why are not specified. The reasons are perhaps alluded to in the passage where it is said that the Croats' ancestral home is constantly plundered by Franks, Turks and Pechenegs (c. 31, 85-87) ${ }^{21}$. Even though this information belongs to a different time plain, it may be that the exposure of both the Croat and Serb ancestral lands from external attacks is implied as the main reason for their migration.

Earliest chronology in the so-called Dalmatian dossier of the DAI. Recently it has been - rightly - inferred that the description of events in the Dalmatian dossier of the DAI does not represent an historical chronology, even though it may be presumed that the events closer to Constantine Porphyrogennetos's own time are much more reliably dated [1, p. 190]. Therefore, the attempts to pinpoint the exact time of the earlier events amount to nothing more than sheer speculations (see, for example, attempts in [67, pp. 56ff.; 65, pp. 144ff.]). Of some use might be the order in which the events are arranged as it would suppose that this, at least, reflects in general the sequence in which they occurred (departures from this are due to narrative peculiarities). What may be termed as the Dalmatian dossier is comprised in three chapters of the DAI (c. 29, $30,31)$. The order of the events related to the earliest history is given in the synoptic table below (see Table 2).

What may be surmised from the comparison is that, given its position in the master narrative comprising of all the three Dalmatia-related stories up to the point when the Croats are said to have settled down in Dalmatia, the account of the Dalmatian Croats' split-off group's arriving to Illyricum and Pannonia seems to refer to some later times. The intrinsic narrative logic of the integrated story would suggest that, since the entire Dalmatia with all its nations and cities is said to have been under Byzantine rule from the reign of Heraclius until the reign of Michael II, the creation of another Croat polity is - in the representation of the past as offered - to be rather connected to the time of the latter emperor.

Illyricum, Pannonia and Dalmatia in the DAI. The last of the three interim issues investigated here is the examination of what was understood in the DAI under the regions of Illyricum, Pannonia and Dalmatia. Illyricum is mentioned only once in the entire treatise ${ }^{22}$, but since the perspective is eastern Roman, i.e. Byzantine, it is fairly certain that the Illyricum of the $D A I$ refers to the late Roman prefecture of Illyricum. Furthermore, as it is mentioned in connection to Pannonia, it surely signifies the part of the prefecture that was geographically adjacent to Pannonia ${ }^{23}$. 
Table 2. Synoptic table for the Dalmatian dossier in the $D A I$ (c. 29, 30, 31)

\begin{tabular}{|c|c|c|}
\hline DAI, c. 29 & $D A I$, c. 30 & $D A I$, c. 31 \\
\hline $\begin{array}{l}\text { 3-11: the resettlement of Romans to } \\
\text { Dalmatia, and the foundation of } \\
\text { Spalato and Diocleia in the time of } \\
\text { the emperor Diocletian }\end{array}$ & $\begin{array}{l}\text { 14-17: the emperor Diocletian built } \\
\text { Salona and Spalato }\end{array}$ & $\begin{array}{l}\text { 11-14: the emperor Diocletian } \\
\text { brought the Romans to Dalmatia and } \\
\text { settled them there }\end{array}$ \\
\hline $\begin{array}{l}14-15 \text { : the territory possessed by } \\
\text { Romans used to extend as far as the } \\
\text { river Danube }\end{array}$ & $\begin{array}{l}\text { 8-14: the province of Dalmatia, } \\
\text { which used to extend as far as the } \\
\text { confines of Dyrrachium, the } \\
\text { mountains of Istria and the river } \\
\text { Danube, was under the rule of the } \\
\text { Romans before it was taken by Slavs }\end{array}$ & \\
\hline \multirow[t]{2}{*}{$\begin{array}{l}\text { 15-18: beyond the river Danube } \\
\text { lived Slav nations, who were also } \\
\text { called Avars }\end{array}$} & $\begin{array}{l}\text { 18-21: a force of cavalry, collected } \\
\text { from the other towns of Dalmatia, } \\
\text { was dispatched from Salona to keep } \\
\text { guard on the river Danube against } \\
\text { the Avars }\end{array}$ & \\
\hline & $\begin{array}{l}\text { 21-23: the Avars had their haunts on } \\
\text { the far side of the river Danube, } \\
\text { where the Turks are now }\end{array}$ & \\
\hline $\begin{array}{l}\text { 18-22: the Dalmatian Romans made } \\
\text { an incursion into the Slav territory, } \\
\text { overcame the Avars and took booty } \\
\text { and prisoners }\end{array}$ & \multirow{2}{*}{$\begin{array}{l}\text { 23-30: the men of Dalmatia crossed } \\
\text { over into the Avar territory, attacked } \\
\text { the Avars when their men and youths } \\
\text { were on a military expedition, and } \\
\text { came back to Salona carrying booty }\end{array}$} & \\
\hline $\begin{array}{l}\text { 22-32: the Romans introduced } \\
\text { frontier station at the river, and the } \\
\text { starting point for advancement of the } \\
\text { exchanging garrison to the station } \\
\text { was the frontier pass called Kleisa } \\
\text { near Salona }\end{array}$ & & \\
\hline $\begin{array}{l}\text { 32-38: the Slavs, who were also } \\
\text { called Avars, ambushed, and } \\
\text { defeated the Romans after they once } \\
\text { more crossed over to their territory }\end{array}$ & $\begin{array}{l}\text { 33-39: another garrison was } \\
\text { dispatched from Salona, they also } \\
\text { crossed over into the Avar territory, } \\
\text { but were defeated and slain or } \\
\text { captured }\end{array}$ & \\
\hline $\begin{array}{l}\text { 38-46: the Slavs proceeded to attack } \\
\text { Salona, took it by a strategem and } \\
\text { settled there }\end{array}$ & $\begin{array}{l}\text { 39-56: the Avars proceeded to attack } \\
\text { Salona and managed to take it by a } \\
\text { strategem }\end{array}$ & \\
\hline $\begin{array}{l}\text { 46-49: the Slavs began to make raids } \\
\text { and took possession of the lands of } \\
\text { the Romans }\end{array}$ & $\begin{array}{l}56-58,60-61 \text { : thereafter, the Avars } \\
\text { made themselves masters of all of } \\
\text { Dalmatia and settled down in it }\end{array}$ & $\begin{array}{l}\text { 15-17: the Romans of Dalmatia were } \\
\text { expelled by the Avars in the time of } \\
\text { the emperor Heraclius }\end{array}$ \\
\hline \multirow[t]{3}{*}{$\begin{array}{l}\text { 49-53: the remaining Romans } \\
\text { escaped to coastal cities and possess } \\
\text { them still }\end{array}$} & $\begin{array}{l}58-60: \text { only the coastal cities held } \\
\text { out against the Avars, and continued } \\
\text { to be in the hands of the Romans }\end{array}$ & \\
\hline & $\begin{array}{l}\text { 61-63: at the time, the Croats were } \\
\text { dwelling beyond Bavaria, where the } \\
\text { White Croats are presently }\end{array}$ & \\
\hline & $\begin{array}{l}\text { 63-67: one part of the Croats split } \\
\text { off, came to Dalmatia and found the } \\
\text { Avars in possession of that land }\end{array}$ & $\begin{array}{l}\text { 8-11: the Croats of White Croatia } \\
\text { arrived to Dalmatia in refuge to the } \\
\text { emperor Heraclius, at that time when } \\
\text { the Avars fought and expelled the } \\
\text { Romans }\end{array}$ \\
\hline
\end{tabular}


End of Table 2

\begin{tabular}{|c|c|c|}
\hline DAI, c. 29 & $D A I$, c. 30 & DAI, c. 31 \\
\hline \multirow[t]{3}{*}{$\begin{array}{l}\text { 54-58: the whole of Dalmatia and } \\
\text { the nations in it were subject to the } \\
\text { empire of the Romans since the reign } \\
\text { of Heraclius }\end{array}$} & \multirow[t]{2}{*}{$\begin{array}{l}\text { 67-71: the Croats and Avars fought } \\
\text { one another for some time, until the } \\
\text { Croats prevailed, killed some of the } \\
\text { Avars, and subjugated the remainder, } \\
\text { and from that time Dalmatia has } \\
\text { been possessed by Croats }\end{array}$} & $\begin{array}{l}\text { 17-21: by command of the emperor } \\
\text { Heraclius, the Croats defeated and } \\
\text { expelled the Avars, and by the } \\
\text { mandate of the same emperor, they } \\
\text { settled down in that same country of } \\
\text { the Avars, where they now dwell; at } \\
\text { that time the Croats had for prince } \\
\text { the father of Porgas } \\
58-60 \text { : the prince of Croatia had ever } \\
\text { since the time of the emperor } \\
\text { Heraclius been subservient and } \\
\text { subject to the emperor of the Romans }\end{array}$ \\
\hline & & \multirow[t]{3}{*}{$\begin{array}{l}\text { 21-25: the emperor Heraclius had } \\
\text { the Croats baptized by bringing } \\
\text { priests from Rome; at that time the } \\
\text { Croats had Porgas for their prince }\end{array}$} \\
\hline & $\begin{array}{l}\text { 75-78: one part of the Croats who } \\
\text { came to Dalmatia split off and } \\
\text { possessed themselves of Illyricum } \\
\text { and Pannonia, where they also had } \\
\text { an independent prince } \\
78-82 \text { : for a number of years the } \\
\text { Croats of Dalmatia also were subject } \\
\text { to the Franks }\end{array}$ & \\
\hline $\begin{array}{l}\text { 58-66: the cities and nations of } \\
\text { Dalmatia became independent in the } \\
\text { time of the emperor Michael II }\end{array}$ & $\begin{array}{l}\text { 82-88: the Croats of Dalmatia } \\
\text { rebelled against the Franks and won } \\
\text { their independence }\end{array}$ & \\
\hline $\begin{array}{l}233-236: 500(!) \text { years has passed } \\
\text { from the migration from Salona to } \\
\text { Ragusa till the present year, which is } \\
\text { A.D. } 949\end{array}$ & $\begin{array}{l}71-75 \text { : the rest of the Croats who } \\
\text { stayed behind in their ancestral land } \\
\text { are now subject to Otto, the king of } \\
\text { Francia, and maintain good relations } \\
\text { with the Turks }\end{array}$ & $\begin{array}{l}\text { 3-6: the Croats of Dalmatia are } \\
\text { descended from the White Croats } \\
\text { who live beyond Turkey and next to } \\
\text { Francia }\end{array}$ \\
\hline
\end{tabular}

Pannonia is mentioned directly three times and implied three more. Apart from the mention in connection to the Croat split-off group, Pannonia is also said to have been in possession of Goths before their transfer to Thrace (c. 25, 24-25), and is identified as the region where the Lombards were dwelling, and where now the Turks (i.e. Magyars) live (c. 27, 30-31). Given the latter, it may be presumed that it is also implied as the territory of Gepids who are said to have been later divided off by the Lombards and Avars and previously lived in the area of Sirmium (as well as that of Singidunum) (c. 25, 21-23), and as the territory of Turks who are also singled out as holding Sirmium (and Belgrade as well) (c. 40, 29-32). Moreover, the Turks' is also the land between the rivers Danube and Sava (c. 42, 19-
20). Sirmium (and Belgrade, too) is mentioned as one of the landmarks along the Danube as well (c. 40, 31).

Dalmatia, understandably, received much more attention. It is said to be the most illustrious of all the provinces of the West (c. 30, 11-13) and the most fair country (c. 30, 60-61). Dalmatia is described as extending from the confines of Dyrrachium $^{24}$ as far as the mountains of Istria and the river Danube (c. 30, 8-11). Its territory is implicitly matched with the territory that is said to have once been - i.e. prior to the Slav conquest possessed by Romans and extending to the river Danube (c. 29, 14-15). In the tenth century, the Byzantine theme of Dalmatia encompassed all the remaining Byzantine possessions on the eastern Adriatic save those that belonged to the theme of 
Dyrrachium $^{25}$. The theme of Dalmatia is referred to in the DAI as the "whole of Dalmatia" separated from other nations (the Croats, Serbs, Zachlumians, Terbuniotes, Kanalites, Diocletians and Arentanians) that are about it (c. 29, 56-58; cf. also 32, 24-25), and as the cities of Dalmatia (c. 29, 61-63, 110) as well as the islands of Dalmatia (c. 29, 285-293). All these other nations are said or implied to live in the territory of the former (Roman-time) Dalmatia, and their countries, as presented in the DAI, extended in some cases beyond the boundaries of what is known as the late Roman province of Dalmatia (including Praevalitana). Accordingly, the Croats are said to border with the Turks on the latter's southern side (c. 40, 43-44), and, simultaneously, the Turks are pointed out as possessing the land between the Danube and the Sava (c. 42, 1920), which would suppose that the Croats and Turks must have shared a border in this area and that this portion was meant under the Danube to which Dalmatia is said to stretch (assuming that the $D A I$ has not confused the Sava with the Danube ${ }^{26}$ ). Consequently, it may be that the $D A I$ has simply (but not particularly precisely) translated the contemporaneous geopolitical circumstances to earlier times.

There is however an alternative explanation. Constantine Porphyrogennetos may have had the Croats of Illyricum and Pannonia before his eyes, and since they are presented as a group that was to put it in the phrasing of the $D A I$ - descended from the Croats of Dalmatia but no longer extant as a polity in Constantine's own time, he merely included them - following the logic of equating the ethnic identity affiliation with the political overlordship - under their Dalmatian counterparts which, by extension, meant that they also could be regarded as part of Dalmatia ${ }^{27}$. Finally, yet another explanation might lie in the sphere of the imaginary, since the Danube could have been used in this context as a symbolic marker that divided the Romans from the barbarians, a perceived landmark of liminality between the two culturally disparate worlds ${ }^{28}$. Therefore, in regard to the northern boundary of Dalmatia in the $D A I$, the Danube might have been used as the divide symbol rather than the concrete watercourse, even though both of these meanings have been merged ${ }^{29}$.

Analysis and discussion. Let us now return to the research questions related to the two sentences from the DAI that are the focus of this investigation. Before we proceed, we shall make a cursory point related to the recent state of research of the early medieval ethnic identities. Succinctly put, the ethnic identity was a quite different category in early medieval societies than it is in modern societies, even though some national historiographies still seem slow in escaping the grips of nineteenth-century perceptions ${ }^{30}$. To sum up, the current socio-anthropological discourse is that the early medieval ethnic identity is a situational construct, a fluid and constantly created and re-created subjectivity of the group that is based on the perception of the group's history and traditions. The ethnic identity is created by the group from within the group but also from outside the group, through the perception of differences toward other groups. At the same time, the ethnic identity is also imposed by external observers that control the discourse thanks to their political as well as ideological and cultural domination.

In other words, the feeling of ethnic affiliation in the early Middle Ages had much less to do with the awareness of common descent and shared cultural traits than with political, ideological and economic interests. It was primarily a matter of the élite and contingent on the success of the fundamental (eponym) group (or several such groups united by a strong appreciation of shared kinship and origin) in imposing their own traditions and values on other groups and populations ${ }^{31}$. In the case of the Croats, there could have really been several groups since the $D A I$, our main source for the Croatian origo gentis, has preserved the tradition about seven brothers and sisters who purportedly led the Croat split-off group during their migration to Dalmatia (c. 30, 63-67). Therefore, being part of an early medieval people (gens, natio) was more than anything else an ideological political category, and especially in the perception of external observers. Consequently, the "Croats" are most likely to have been - in early medieval terms - an ethnic-identity label for various populations that began to identify themselves with the eponym group and, in this way, to form an ethnie. The label could also be applied only to members of the core group(s), i.e. the élite as holders of power and influence, through which the ethnonym would become a marker for authority, that is, a population or populations, or even another ethnie might have 
been perceived as "Croat" in the eyes of external observers if the Croats imposed their rule or exerted their influence over these populations, or if a member of the Croat élite became their ruler.

The last remark aims directly at the actual meaning of the story in the DAI about part of the Croats splitting off and possessing Illyricum and Pannonia. Taken at face value, it would mean a migration of a portion of the Croat ethnie from Dalmatia to a new abode (which Constantine Porphyrogennetos, strictly speaking, says), or it could signify the transfer of political dominion. Not discarding a priori the possibility that there really was another Croat migration (but certainly nothing like a large-scale movement, which may also be valid remark for their original, assumed, migration from the ancestral land), it must be said that the archaeological and anthropological research notwithstanding methodological limitations - has so far not yielded any evidence to support such an interpretation. Craniometric analyses of skeletal remains discovered in graves located in the area from the Adriatic into the deep inland seem to indicate that the so-called "Old Croat" populations gradually spread from the coast into the interior to southern Pannonia in the tenth to thirteenth centuries $[81 ; 82$, pp. 106-107;83]. The Dalmatian Croat(icized) populations have been determined as clearly differing by their anthropometric and craniometric traits from the continental populations from Vukovar and Bijelo Brdo - which is actually suggestive of the predominance of pre-Slav (and pre-Croat) population substrate in the post-Roman Dalmatia while the populations from the site Gomjenica near Prijedor (based on archaeological finds, the site has been attributed to the so-called Bijelo Brdo cultural complex) are included in the Dalmatian Croat(icized) populations [80, pp. 105-106]. Slow penetration of the Croat influence to the north is further backed by jewelry finds from the same period, which may be taken as evidence for direct contacts between the Dalmatian Croat and south Pannonian Slav cultural circles [86, pp. 138-141; 87, pp. 136-142]. Under the assumption that these artifacts were specific to the Croat cultural circle to the point of being used as identity markers, both the anthropological and archaeological findings definitely suggest that the early Croats had not settled at all in southern Pannonia during their original (assumed) north-south migration, even though it is possible - if we accept that the Croat migration happened at some point and that the Croats traversed, on their southbound move, the region between the Danube, Sava and Drava that there might have been minor Croat groups staying behind in this area and eventually fading away in the mass of other Slav(icized) populations. It would appear that the spreading of the so-called "Old Croat" populations from the south to the north belongs to the period from the tenth century onward and that it is related to the altered political situation, the strengthening and expansion of the early Croat state.

Based on all of these assumptions it is more likely that the ethnonym "Croats" and the purported reverse migration hide the circumstance of the transfer of political dominion. This would mean that Constantine Porphyrogennetos, as already argued, identified the political overlordship with the ethnic presence, i.e. ethnicity. When could this presumed transfer of political dominion have taken place? Certainly, before the tenth century since there could not have been an independent prince in "Pannonia and Illyricum" at the time when Constantine Porphyrogennetos was compiling his treatise (the mid-tenth century), which he himself alludes to by using the past tense in connection to this Croat prince. The ninth century is the only possible candidate given that southern Pannonia was still part of the Avar Kaganate in the late eighth century.

Let us now try to determine what Constantine Porphyrogennetos may have meant under Illyricum and Pannonia. A logical point of departure is the assumption that, in his use of provincial administrative designations, he had before his eyes the contemporary situation as well as the situation in Late Antiquity since he also had written sources from that time at his disposal, and he is known to have used them. This duality could explain apparent illogicalities that exist in his account regarding the use of the names of Pannonia, Dalmatia and Illyricum, i.e. their overlapping. As has been pointed out, under Illyricum the early Byzantine sources regularly understood the prefecture of Illyricum which was bound on the northwest by the Sava and the Upper Drina watercourses. The late Roman Pannonia encompassed the area from the northern slopes of the Bosnian mountain range just below the Sava to the Drava and Danube in the north. Dalmatia 
stretched from the southern borderline of Pannonia down to the Adriatic coast. Assuming, sensibly, that the Illyricum and Pannonia mentioned in the account have to be areas in immediate proximity to each other, since they stood under the authority of one and the same prince, at first there seems to be a plenty of possibilities for various speculations.

A proposed solution to the conundrum lies, as I see it, in the circumstances that existed in Late Antiquity. In principle, the label Pannonia could be applied to all of the territory included in the late Roman Pannonian provinces (Pannonia Prima, Valeria, Pannonia Savia, and Pannonia Secunda), or, in the broadest sense, could denote the diocese of Pannonia (dioecesis Pannoniarum, also known as the diocese of Illyricum) ${ }^{32}$. Following the collapse of the Roman administrative system in the Middle Danube region, southern Pannonia between the rivers Sava and Drava retained a certain value for the eastern Roman government, even though it had been almost continuously under the sway of various barbarian groups (the Ostrogoths, Gepids, Lombards) (for details, cf. [36, pp. 167ff; 38, pp. $193 \mathrm{ff}]$.$) . The Eastern Roman Empire$ succeeded ultimately in preserving, until the Avar invasion, the southeasternmost part of the Second Pannonia (Pannonia Secunda) with the town of Bassianae (Donji Petrovci east of Sremska Mitrovica) as a forward stronghold. This area was also known in the early Byzantine literary sources as "the Herul land" ( $\dot{\eta}$ 'E $\lambda o v ́ \rho \omega \nu \chi \omega ́ \rho \alpha$ ), after the Heruls who were first settled there in $512^{33}$, and it was joined, together with Sirmium as long as the city was in Byzantine hands, with the prefecture of Illyricum and considered part of Illyricum. Therefore, it may be assumed that Constantine Porphyrogennetos's Pannonia refers to the region between the rivers Sava, Drava and Danube (modern northwestern Croatia without Medjimurje, Slavonia and western Syrmia), and Illyricum to the Sirmium-Bassianae area, i.e. eastern Syrmia ${ }^{34}$.

It is no coincidence that this area matches with the so-called Principality, or Duchy, of Lower Pannonia, or the regnum inter Savo et Dravo flumine [7, a. 884, p. 113], which was created by Franks after they had toppled the Avar Kaganate in the early ninth century. Hence, it seems that Constantine Porphyrogennetos had precisely the
Principality of Lower Pannonia in mind, whose duke enjoyed a certain independence under the Frankish overlordship. One of the features of an independent position was the right to send embassies. Frankish sources suggest that it was customary for subject peoples to send envoys to the Frankish emperor. Consequently, Constantine Porphyrogennetos's remark about the "Croat" prince of Illyricum and Pannonia dispatching envoys is in essence accurate. Especially close relations between the duke of Lower Pannonia and the prince of Croatia, as surmised from the $D A I$, should be seen as nothing more than an amicable relationship resulting from the same concerns in line with overarching interests of their Frankish overlords as they both governed their respective territories under the tutelage of the Franks (the duke of Lower Pannonia remained a Frankish vassal until the collapse of his regnum due to the advent of Magyars ${ }^{35}$, while the Croat prince seems to have enjoyed a significant freedom of action from very early on).

Proposed reconstruction for a conclusion. Based on the analysis and discussion conducted above I argue that the separation of Croats and their move into southern Pannonia, as depicted in the $D A I$, should not be understood as an actual migration but as a case of the identification of political dominion with ethnicity. Furthermore, the Illyricum and Pannonia of the $D A I$ seem to fully correspond with the territory of the so-called Principality of Lower Pannonia during the ninth century. Finally, the cordial relations between the duke of Lower Pannonia and his counterpart in Croatia were - at least at first - the result of the political unity imposed by their Frankish overlords, since both of these polities were Frankish creations.

The identification of political dominion with ethnicity suggested here means that, in Constantine Porphyrogennetos's view, the Croats were actually in control of southern Pannonia, i.e. the so-called Principality of Lower Pannonia. To be sure, it is usually believed that, during the first quarter of the tenth century, the Croat polity of Dalmatia managed to extended its rule and influence over some portions of southern Pannonia with the center at Siscia (see [35, pp. 200ff.]). Thus, it may well be that Constantine had this in mind. However, such an explanation cannot account for the claim that the Croats possessed 
Illyricum and Pannonia, that is, the entire Lower Pannonia, unless he made a blunder, which is not likely considering that the developments mentioned above were close to his own time and age. Consequently, we have to look somewhere else for an answer. It is known that the Franks intervened twice against the local dukes in Lower Pannonia: there was a proper war fought against Liudewit (819-822), while Ratimar was overthrown in a single campaign (838) (apart from [35, pp. 157-168, 175-178], cf. also [91, pp. 307$310,312,314$; 11, pp. 60-71, 99-100]). The sources are tacit on what happened with the Principality after Ratimar's removal (for that matter, they have nothing to say about what happened immediately after Liudewit had been ousted, although we may assume that Ratimar became Liudewit's successor at some point, possibly in 831), but the Franks would certainly have been still very interested in finding a permanent solution to stabilize the southeastern frontier area of their empire. If this suggestion holds water, it is quite possible that, looking for a suitable candidate to fill the position of the duke of Lower Pannonia, they turned their attention to the Adriatic coast.

I would thus propose that the Franks chose as Ratimar's successor a member of the Croat élite from the nearby Croat polity in Dalmatia, which, at that time, had been faithfully adhering to the Franks for quite a while. Attracting this presumed member of the Croat warrior élite and installing him as the duke of Lower Pannonia would not have been an unusual course of action for the Franks. Similarly, the former duke of Nitra, Pribina, after he had been forced to flee from the duke of Moravia, Moimir I, was eventually established as the Frankish vassal duke $(d u x)$ of Lower Pannonia north of the Drava and centred on Moosburg (modern Zalavár). The new duke of Lower Pannonia between the Sava and the Drava would have doubtlessly been loyal to those who had appointed him, the more so since he would have lacked a power base in the region. Moreover, it may be assumed that the south Pannonian Slavs would not have perceived the rule of a duke of the Croat descent as something alien since there was no language barrier or conflicting customs or practices. The presumable Frankish support for their appointee would have certainly suppressed any opposition to such an arrangement. From the perspective of a Byzantine emperor writing in Constantinople one century after the fact, with no clear understanding of the situation in distant times and with no access to accurate sources, and in an attempt to elucidate the past as best as he could, it might have indeed appeared as if the Croats had also established their rule in southern Pannonia. If the proposed reconstruction is correct, the move was a success for the Franks given that there is no more news in the sources of troubles in the Frankish southeast that were caused by unruly and disobedient dukes. The last known duke of Lower Pannonia, Brazlavo, was to the last a faithful follower of the Frankish emperor, and even entrusted with the control of Lower Pannonia north of the Drava as his fief as well [35, pp. 189193; with 91, pp. 92, 119; 11, pp. 245, 271].

For the final note I would like to suggest that the designations "Pannonian Croatia" and "Posavian Croatia", which are commonly used by modern scholars to denote the early medieval Slav principality in southern Pannonia, be dispensed with, since such a Croat polity had never existed. The renown Croatian medievalist, Nada Klaić, consistently argued against the use of both of these labels, emphasizing that they are a scholarly invention by modern historians and not based on contemporary sources (cf., for example, $[53$, pp. 40, 45, 51]). They may perhaps only be used in a broad geographical sense, with a clear idea of their modern context, where Posavian Croatia has a narrower meaning than Pannonian Croatia. Instead of these anachronistic and unwarranted names, Lower Pannonia or the Principality or Duchy of Lower Pannonia, or perhaps even the Sava-Drava Principality (after the regnum inter Dravo et Savo flumine from the Annales Fuldenses) should be preferred for the early medieval polity of south Pannonian Slavs that existed in the region between the Sava, the Drava and the Danube under Frankish tutelage during the better part of the ninth century.

\section{NOTES}

1 This paper is a re-written, expanded and updated version of the article first published in [34], but the basic arguments are unchanged.

${ }^{2}$ For a brief survey on the $D A I$ and its purpose, with references to the relevant scholarship: [37, pp. 2527]. Now see also: [71, pp. 130-137; 56, pp. 41-58]. 
${ }^{3}$ About the production process of the DAI, cf. [49, pp. 306-310]. However, his overall appraisal of Constantine Porphyrogennetos's effort seems to be too harsh. For less critical assessment, see [78, pp. 9798]; with [8, pp. 553-554]. For a humorous but to-thepoint justification of obstacles that the emperor might have met in the formation of the text: [77, pp. 189-192].

${ }^{4}$ Cf. also [71, pp. 135-136], and [71, pp. 54-60] for the compilation method.

${ }^{5}$ For an example of such an approach, despite some interesting assertions: [9]. A critical appraisal of Borri's approach and methods: [5, pp. 45-49].

${ }^{6}$ The idea behind this assertion is inspired by the approach of the so-called Viennese school to the construction of early medieval identities, but the concept of a firm group identity embedded in an immutable binding core of tradition is implicitly abandoned, since the acceptance and maintaining of an ethnic identity had to be negotiated and reaffirmed, especially under external ideological-political and cultural influences and in adverse situations, however, a group ethnic identity could be inherited and exercise a sufficiently powerful constraint upon its individual members. Cf. [73]; with [48, pp. 26-47; 59, pp. 87-96].

${ }^{7}$ The basic conclusions of this paper have been reproduced in [1, p. 300].

${ }^{8}$ This translation differs somewhat from the standard translation by R.J.H. Jenkins in [14, p. 143]. For the peculiarities related to the translation of this spot, cf. [62, pp. 352-356].

9 For an interpretation and a possible meaning of the story about the Croats of Dalmatia revolting against Franks, cf. [37, pp. 29, 31-32]. For a different take, see [2, pp. 144-146, 157-158, 163-164], who explains the story as an invented event that served the military élite as a structural ideological element to open a way for their political emancipation from the Franks and the formation of a new independent ethnopolitical organism in the Frankish Dalmatia - the regnum Chroatorum. However, it seems far-fetched to conclude that the story of a hard-won war against the Franks was entirely a fabrication, and the only other incident of such magnitude in the wider area was the anti-Frankish rebellion of the Lower Pannonian duke Liudewit.

${ }^{10}$ M. Suić [88, pp. 94-95] has interpreted this place as indicating a foedus (symmachía) existing between the two polities, where the prince of Croatia was primus inter pares and, in recognition of his primacy, the prince of the Croats in southern Pannonia sent him embassies with gifts. It might be worthwhile to address here a question of the English rendering of Slavic ruler titles. In the Croatian scholarship, it has been customary to use the word "knez" ( $d u x$ or comes in Latin) as a title for early medieval Croat rulers before Tomislav who is usually taken to be the first king of
Croatia, as well as for early medieval Slavic rulers in southern Pannonia. The word "knez" is better to render in English as a "prince", since a "duke", which is commonly used in English-speaking scholarship (see, however, [29, pp. $253 \mathrm{ff}$.]), translates in Croatian as "vojvoda" and does not necessarily denote a ruler in his own right. The problem which an English-speaking scholar might encounter when trying to properly translate these titles into English is shown, for example, in F. Curta's two monographs about history of southeastern and eastern Europe in the Middle Ages. In his Southeastern Europe in the Middle Ages 500 1250, Curta uses the title "duke" for Borna [16, p. 135], Liudewit [16, p. 135], Trpimir [16, p. 137], Branimir [16, pp. 140-141], and Muncimir [16, p. 140], and "prince" for Tomislav [16, p. 137] and Domagoj [16, p. 140], which is not consistent. His somewhat of a dilemma is alluded to in the remark "early dukes or princes" [16, p. 141]. Similarly, in his Eastern Europe in the Middle Ages (500-1300), Curta uses the title "duke" for Borna [17, p. 109], Liudewit [17, p. 109], Brazlav [17, p. 110], and Tomislav [17, p. 325], but "chieftain" for Ratimir [17, p. 110] and "prince" for Branimir [17, p. 591]. In German, the word "Fürst" is used, which is more appropriate. Therefore, in this paper the word "prince" is used for the Greek archon, whereas "duke" denotes a ruler under tutelage. For a discussion on Latin and Slavic titles of early medieval Croat rulers, cf. [31].

${ }^{11}$ The translation by I. Ševčenko has been slightly modified.

12 A partial survey of Croatian scholarship on this matter is also offered in [1, pp. 298-301].

${ }_{13}$ J.V.A. Fine Jr. [30, p. 20] rightly expresses reservation with regard to the term "Pannonian Croatia", but he uses it nevertheless later in his text [30, pp. 21, 49, 72].

${ }^{14}$ In the Croatian scholarship, the names of these south Pannonian Slav dukes are regularly rendered in their Slavicized / Croaticized forms as Ljudevit, Ratimir, and Braslav.

${ }^{15}$ This is followed in [60, p. 371 (note 19)].

${ }^{16}$ Similarly to this was already maintained in $[61$, pp. 136-138].

${ }^{17}$ Noricum: [76, p. 279; 43, p. 256; 44, p. 340]. Doclea: [45, pp. 22-23; 46, pp. 337-338; 47, pp. 112113]. Cf. also [32, p. 91].

${ }_{18}$ This is a remark that has already been stressed by the author in several of his papers. Cf., for example, [38, p. 186, with note 5].

${ }^{19}$ Simplistic is the claim in [55] that Constantine Porhyprogennetos considered the Diocleatians to be Serbs, even though he does not mention them as such. Komatina's arguments are all quite circumstantial and the fact that Diocleia is not mentioned as a country settled by Serbs is explained as the emperor's failing to follow strictly to the principle of listing countries and peoples in details. 
${ }^{20}$ This was first observed in [62, pp. 328-329] (even though Lončar mentions that the words "in refuge" might allude to a reason), and accentuated in [22, p. 112, note 83].

${ }^{21}$ In the previous chapter of the $D A I$ (c. $30,71-$ 75) it is, however, said that the Croats of White Croatia are subject to the king Otto of Francia and in friendly relations with the Turks (i.e. Magyars), which would suppose that the attacks by Franks and Magyars predated these new political arrangements.

22 The Illyria mentioned in the chapter devoted to the Iberians (c. 45,159$)$ is the Armenian province of Aghori (cf. [50, p. 177]).

${ }^{23}$ That this Illyricum was adjacent to Pannonia had already been suggested in [39, p. 31].

${ }^{24}$ These confines are, on their northern side, set by Constantine Porphyrogennetos at Ulcinium (DAI, c. 30, 95-96).

${ }^{25}$ On the theme of Dalmatia in the late ninth and the tenth centuries, see [28, pp. 165-191]. On the theme of Dyrrachium in the ninth and the tenth centuries, see [51, pp. 337ff.].

${ }^{26}$ For misidentifications of the Danube in ancient literary sources and Sirmium as a switch point between the two hydronyms for this watercourse (Danubius/Ister), cf. [19, pp. 138-139].

${ }^{27}$ It is perhaps instructive as well that the $13^{\text {th }}$-century chronicler, Thomas archdeacon of Split, when describing the extent of the kingdom of Dalmatia and Croatia, its northern border also sets at the banks of the Danube [90, c. 13, pp. 60-61].

${ }^{28}$ For the construction of the Danube as a sociocultural frontier in Antiquity, see [70, pp. 751-755].

${ }^{29}$ It is worth noting that B. Ferjančić [27] does not dwell on these issues related to the boundaries of Dalmatia.

${ }^{30}$ For this problem in the context of modern Croatian historiography, cf. [4].

${ }^{31}$ For a discussion on identities in post-Roman Dalmatia cf. [21; 22, pp. 64-73].

${ }^{32}$ Main sources for the administrative division of the later Roman Empire are the Notitia Dignitatum [72] and the Laterculus Veronensis [58].

33 The phrasing is by Menander Protector [69, fr. 5.4, pp. 52-53]. Cf. [38, p. 200, with note 60, p. 219].

${ }^{34}$ Constantine Porphyrogennetos's Illyricum and Pannonia are reminiscent of the Illyricum and Pannonia mentioned in the Annales Laureshamenses' account of the Frankish campaign against the Avars in 791 [6, a. 791, p. 34]. However, since the perspective is here decidedly western, it is most likely that southwestern parts of the former diocese of Pannonia, i.e. Noricum mediterraneum (the territory of modern Slovenia), were meant under the Illyricum. Cf. [35, pp. 150-151].

${ }^{35}$ For details on political developments in southern Pannonia during the ninth century, cf. [35, pp. 154-194].

\section{REFERENCES}

1. Alimov D.E. Etnogenez khorvatov: formirovanie khorvatskoy etnopoliticheskoy obshchnosti v VII-IX vv. [Ethnogenesis of Croats: Formation of the Croatian Ethnopolitical Community in the $7^{\text {th }}-9^{\text {th }}$ Centuries]. St. Petersburg, Nestor-Istoriya Publ., 2016. 380 p.

2. Alimov D.J. Hrvati, kult Peruna i slavenski gentilizam (Komentari na hipotezu Ante Miloševića o identitetu Porina i Peruna) [Croats, the cult of Perun and Slavic "gentilism". (A Comment on the hypothesis of Ante Milošević about the identity of Porin and Perun)]. Starohrvatska prosvjeta, 2016, vol. 3, no. 43, pp. 141-164.

3. Ančić M. U osvit novog doba. Karolinško carstvo i njegov jugoistočni obod [At the dawn of a new age. The Carolingian empire and its southeastern edge]. Milošević A., ed. Hrvati i Karolinzi. Rasprave $i$ vrela. Split, Muzej hrvatskih arheoloških spomenika, 2000, pp. 70-103.

4. Ančić M. Što "svi znaju” $i$ što je "svima jasno". Historiografija i nacionalizam [What is it that 'everyone knows' and is 'clear to everyone'? Historiography and nationalism]. Zagreb, Hrvatski Inst. za povijest, 2008. $270 \mathrm{p}$.

5. Ančić M. Migration or Transformation: The Roots of the Early Medieval Croatian Polity. Dzino D., Milošević A., Vedriš T., eds. Migration, Integration and Connectivity on the Southeastern Frontier of the Carolingian Empire. Leiden; Boston, Brill, 2018, pp. 43-62. (East Central and Eastern Europe in the Middle Ages, 450-1450; vol. 50).

6. Annales Laureshamenses. Pertz G.H., ed. Annales et chronica aevi Carolini. Vol. I. Hannover, Hahn, 1826, pp. 19-60. (Monumenta Germaniae historica, Scriptores; vol. I).

7. Annalium Fuldensium Continuatio Ratisbonensis. A. 882-897. Kurze F., ed. Annales Fuldenses sive Annales regni Francorum orientalis. Hannover, Impensis Bibliopolii Hahniani, 1891, pp. 107-131 (Monumenta Germaniae historica, Scriptores rerum Germanicarum; vol. 7).

8. Beaud B. Le savoir et le monarque: le Traité sur les nations de l'empereur byzantin Constantin VII Porphyrogénète. Annales. Économies, Sociétés, Civilisations, 1990, vol. 45 (3), pp. 551-564.

9. Borri F. White Croatia and the Arrival of the Croats: an Interpretation of Constantine Porphyrogenitus on the Oldest Dalmatian History. Early Medieval Europe, 2011, vol. 19 (2), pp. 204-231.

10. Bösendorfer J. Crtice iz slavonske povijesti s osobitim obzirom na prošlost županija: križevačke, virovitičke, požeške, cisdravske baranjske, vukovske i srijemske te kraljevskog i slobodnog grada Osijeka u srednjem i novom vijeku [Sketches from the Slavonic 
history with special regard to the past of the županias of Krizevci, Virovitica, Pozega, Cis-Dravian Baranya, Vukovo and Syrmia, and the free royal city of Osijek in Middle and Early Modern Ages]. Osijek, Tiskom J. Pfeiffera, 1910. $482 \mathrm{p}$.

11. Bowlus Ch.R. Franks, Moravians, and Magyars. The Struggle for the Middle Danube, 788 907. Philadelphia, Univ. of Pennsylvania Pr., 1995. xviii, 420 p.

12. Budak N. Slavic ethnogenesies in modern Northern Croatia. Bratož R., ed. Slovenija in sosednje dežele med antiko in karolinško dobo. Začetki slovenske etnogeneze. Vol. 1. Ljubljana, Narodni Muzej Slovenije, 2000, pp. 395-402. (Situla; vol. 39).

13. Bury, J.B. A History of the Later Roman Empire from Arcadius to Irene (395 A.D. to 800 A.D.). Vol. II. London, Macmillan, 1889. xxiv, 579 p.

14. Constantine Porphyrogenitus. De administrando imperio. Moravcsik Gy., Jenkins R.J.H., eds. Washington, D.C., Dumbarton Oaks Center for Byzantine Studies, 1967. ix, 341 p. (Corpus fontium historiae Byzantinae. Series Washingtonensis; vol. 1).

15. Constantinus Porphyrogenitus. De vita Basilii. Ševčenko I., ed. Chronographiae quae Theophanis continuati nomine fertur liber quo Vita Basilii Imperatoris amplectitur. Berlin; Boston, De Gruyter, 2011. xii, 501 p. (Corpus fontium historiae Byzantinae. Series Berolinensis; vol. 42).

16. Curta F. Southeastern Europe in the Middle Ages 500-1250. Cambridge, Cambridge Univ. Pr., 2006. xxviii, $496 \mathrm{p}$.

17. Curta F. Eastern Europe in the Middle Ages (500-1300). Vol. I. Leiden; Boston, Brill, 2019. xxi, 717 p. (Brill's Companions to European History; vol. 19).

18. Curta F. Migrations in the Archaeology of Eastern and Southeastern Europe in the Early Middle Ages (Some Comments on the Current State of Research). Preiser-Kapeller J., Reinfandt L., Stouraitis Y., eds. Migration Histories of the Medieval Afroeurasian Transition Zone: Aspects of Mobility between Africa, Asia and Europe, 300-1500 c.e. Leiden; Boston, Brill, 2020, pp. 101-138. (Studies in Global Social History, vol. 39).

19. Dan A. Between the Euxine and the Adriatic Seas: Ancient Representations of the Ister (Danube River) and the Haemus (Balkan Mountains) as Frames of Modern South-Eastern Europe. Tsetskhladze G.R., Avram A., Hargrave J., eds. The Danubian Lands between the Black, Aegean and Adriatic Seas ( $7^{\text {th }}$ Century BC $-10^{\text {th }}$ Century AD): Proceedings of the Fifth International Congress on Black Sea Antiquities (Belgrade - 17-21 September 2013). Oxford, Archaeopress Publ., 2015, pp. 133-151.

20. Dümmler E. Über dieältesteGeschichte der Slawen in Dalmatien (549-928). Sitzungsberichte der philosophisch-historischen Classe der kaiserlichen Akademie der Wissenschaften, 1856, vol. 20, pp. 353-430.

21. Dzino D. "Becoming Slav", "Becoming Croat": New Approaches in the Research of Identities in Post-Roman Illyricum. Hortus artium medievalium, 2008, vol. 14, pp. 195-206.

22. Dzino D. Becoming Slav, Becoming Croat. Identity Transformations in Post-Roman and Early Medieval Dalmatia. Leiden; Boston, Brill, 2010.272 p. (East Central and Eastern Europe in the Middle Ages, 450-1450; vol. 12).

23. Dzino D. Pričam ti priču: ideološko-narativni diskursi o dolasku Hrvata u De administrando imperio [Telling the stories: Ideological-narrative discourses on the Croat migrations in the De administrando imperio]. Radovi Zavoda za hrvatsku povijest Filozofskoga fakulteta Sveučilišta u Zagrebu, 2010, vol. 42. pp. 153-165.

24. Evans H.M.A. The Early Mediaeval Archaeology of Croatia A.D. 600-900. Oxford, B.A.R., 1989. vii, 378 p. (BAR International Series; vol. 539).

25. Farlati D. Illyricum Sacrum. Tomus secundus. Ecclesia Salonitana, a quarto saeculo aerae Christianae usque ad excidium Salonae. Venice, Apud Sebastianum Coleti, 1753. xii, 636, xlviii, [3] p.

26. Ferjančić B. Struktura 30. glave spisa $D e$ administrando imperio [The structure of the chapter 30 of the De administrando imperio]. Zbornik radova Vizantološkog instituta, 1978, vol. 18, pp. 67-80.

27. Ferjančić B. Dalmacija u spisu De administrando imperio - vrela i putevi saznanja [Dalmatia in the treatise De administrando imperiosources and paths of knowledge]. Zbornik radova Vizantološkog instituta, 1991, vol. 29-30, pp. 9-20.

28. Ferluga J. L'amministrazione bizantina in Dalmazia. Venice, Deputazione di storia patria per le Venezie, 1978. 297 p.

29. Fine Jr. J.V.A. The Early Medieval Balkans: a Critical Survey from the Sixth to the Late Twelfth Century. Ann Arbor, Univ. of Michigan Pr., 1983. xix, $336,[8] \mathrm{p}$.

30. Fine Jr. J.V.A. When Ethnicity Did Not Matter in the Balkans. A Study of Identity in Pre-nationalist Croatia, Dalmatia, and Slavonia in the Medieval and Early-Modern Periods. Ann Arbor, Univ. of Michigan Pr., 2006. xiv, 652 p.

31. Goldstein I. O latinskim i hrvatskim naslovima hrvatskih vladara do početka 12 . stoljeća [On Latin and Croatian titles of the Croatian rulers to the early 12th century]. Historijski zbornik, 1983, vol. 36 (1), pp. 141-164.

32. Goldstein I. Hrvatski rani srednji vijek [The Croatian Early Middle Ages]. Zagreb, Novi Liber, 1995. $511 \mathrm{p}$.

33. Goldstein I. Slika političkog i etničkog stanja u panonskom dijelu Hrvatske (Slavonije) 7.-12. stoljeća 
[A picture of the political and ethnic situation in the Pannonian part of Croatia (Slavonia), $7^{\text {th }}-12^{\text {th }}$ centuries]. Internationales kulturhistorisches Symposion Mogersdorf, 1996, vol. 24, pp. 217-233.

34. Gračanin H. Od Hrvata pak koji su stigli u Dalmaciju odvojio se jedan dio i zavladao Ilirikom i Panonijom: razmatranja uz DAI c. 30, 75-78 [And of the Croats who arrived to Dalmatia one part separated and ruled Illyricum and Pannonia: remarks related to the DAI c. 30, 75-78]. Povijest u nastavi, 2008, vol. 6, no. 11 (1), pp. 67-76.

35. Gračanin H. Južna Panonija u kasnoj antici $i$ ranom srednjem vijeku (od konca 4. do konca 11. stoljeća) [Southern Pannonia in Late Antiquity and the Early Middle Ages (from the late fourth to the late eleventh centuries)]. Zagreb, Plejada, 2011. 455 p.

36. Gračanin H., Škrgulja J. The Ostrogoths in Late Antique Southern Pannonia. Acta Archaeologica Carpathica, 2014, vol. 49, pp. 165-205.

37. Gračanin H., Škrgulja J. Refashioning of Historical Reality: Three Stories by Constantine VII Porphyrogenitus and the Early Medieval History of Croatia. Panov M.B., ed. Samoilovata država $i$ Vizantija: istorija, legenda, tradicija, nasledstvo. Zbornik na trudovi od Megjunarodniot simpozium "Denovi na Justinian I", Skopje, 17-18 oktombri, 2014. Skopje, Univerzitet "Evro-Balkan”, 2015, pp. 24-34.

38. Gračanin, H., Škrgulja J. The Gepids and Southern Pannonia in the Age of Justinian I. Vida T., Quast D., Rácz Zs., Koncz I., eds. Kollaps Neuordnung - Kontinuität. Gepiden nach dem Untergang des Hunnenreiches. Tagung der Internationalen Konferenz and der Eötvös Loránd Universität, Budapest, 14.-15. Dezember 2015. Budapest, Archaeolingua Alapitvany, 2019, pp. 185-274.

39. Grafenauer, B. Prilog kritici izvještaja Konstantina Porfirogeneta o doseljenju Hrvata [Contribution to a critique evaluation of Constantine Porphyrogennetos's account about the migration of the Croats]. Historijski zbornik, 1952, vol. 5, pp. 1-56.

40. Grafenauer B. Vprašanje konca Koceljeve vlade v Spodnji Panoniji [Questions about the end of Kocel's reign in Lower Pannonia']. Zgodovinski časopis, 1952/1953, vol. 6-7, pp. 171-190.

41. Grégoire H. L'origine et le nom des Croates et des Serbes. Byzantion, 1944/1945, vol. 17, pp. 88-118.

42. Guldescu S. History of Medieval Croatia. The Hague, Mouton \& Co., 1964. 351, [1] p.

43. Hauptmann L. Politische Umwälzungen unter den Slowenen vom Ende des sechsten Jahrhunderts bis zur Mitte des neunten Jahrhunderts. Mitteilungen des Instituts für österreichische Geschichtsforschung, 1915, vol. 36, pp. 229-287.

44. Hauptmann L. Entstehung und Entwicklung Krains. Jaksch A. von, Wutte L. Hauptmann A. Mell H., eds. Erläuterungen zum Historischen Atlas der Österreichischen Alpenländer, volume I/4: Kärnten, Krain, Görz und Istrien. Vienna, Holzhausen, 1929, pp. 305-484.

45. Hauptmann L. Konstantin Porfirogenet o porijeklu stanovništva dubrovačkog zaleđa [Constantine Porphyrogenitus on the origin of inhabitants of the Dubrovnik hinterland]. Zbornik iz dubrovačke prošlosti. Milanu Rešetaru o 70-godišnjici života. Dubrovnik, Jadran, 1931, pp. 17-24.

46. Hauptmann L. Kroaten, Goten und Sarmaten. Germanoslavica, 1935, vol. 3, pp. 95-127, 315-353.

47. Hauptmann L. Hrvatsko praplemstvo [The Croatian protonobility]. Razprave Slovenske akademije znanosti in umetnosti, Razred za zgodovinske in družbene vede, 1950, vol. 1, pp. 85-115.

48. Heather P.J. Ethnicity, Group Identity, and Social Status in the Migration Period. Garipzanov I.H., Geary P.J., Urbańczyk P., eds. Franks, Northmen, and Slavs. Identities and State Formation in Early Medieval Europe. Turnhout, Brepols, 2008, pp. 17-49.

49. Howard-Johnston J. The De Administrando Imperio: A Re-examination of the Text and Reevaluation of Its Evidence about the Rus'. Kazanski M., Nercessian A., Zuckerman C., eds. Les Centres protourbains russes entre Scandinavie, Byzance et Orient. Actes du Colloque tenu au Collčge de France en octobre 1997, Paris, P. Lethielleux, 2000, pp. 301-336. (Réalités byzantines; vol. 7).

50. Jenkins R.J.H., Dvornik F., Moravcsik G., eds. Constantine Porphyrogenitus, De Administrando Imperio. Vol. II. Commentary. London, Athlone Pr., 1962. xii, $221 \mathrm{p}$.

51. Kislinger E. Dyrrhachion und die Küsten von Epirus und Dalmatien im frühen Mittelalter Beobachtungen zur Entwicklung der byzantinischen Oberhoheit. Millennium, 2011, vol. 8, pp. 313-352.

52. Klaić N. Povijest Hrvata u ranom srednjem vijeku [The History of the Croats in the Early Middle Ages]. Zagreb, Školska knjiga, 1975. xi, 595 p.

53. Klaić N. Najnoviji radovi o 29, 30. i 31. poglavlju u djelu De administrando imperio cara Konstantina VII. Porfirogeneta [The most recent studies on chapters 29, 30 and 31 of Constantine VII Porphyrogenitus's De administrando imperio']. Starohrvatska prosvjeta, 1985, vol. 15, pp. 31-60.

54. Klaić V. Povjest Hrvata od najstarijih vremena do svršetka XIX. stoljeća. Vol. 1: Vladanje knezova $i$ kraljeva hrvatske krvi (641-1102); Vladanje kraljeva Arpadovića (1102-1301) [The history of the Croats from the earliest times until the end of the $19^{\text {th }}$ century, volume I: The rule of dukes and kings of the Croatian origin (641-1102); the rule of the Árpád kings (11021301)]. Zagreb, Hartman, 1899.318 p.

55. Komatina P. Identitet Dukljana prema De administrando imperio [The identity of Diocletians 
according to the De administrando imperio']. Zbornik radova Vizantološkog instituta, 2014, vol. 51, pp. 33-46

56. Komatina P. Constantine Porphyrogenitus, De administrando imperio and the Byzantine Historiography of the mid- $10^{\text {th }}$ Century. Zbornik radova Vizantološkog instituta, 2019, vol. 56, pp. 39-68.

57. Krause H.L. Res Slavorum in imperiorum occidentalis et orientalis confinio habitantium saeculo IX: diss. historico-critica. Berlin, 1854. $55 \mathrm{p}$.

58. Laterculus Veronensis. Riese A., ed. Geographi Latini minores. Heilbronn, Apud Henningeros Fratres, 1878, pp. 127-129.

59. Liebeschuetz J.H.W.G. The Debate about the Ethnogenesis of the Germanic Tribes. LiebeschuetzJ.H.W.G. East and West in Late Antiquity Invasion, Settlement, Ethnogenesis and Conflicts of Religion, Leiden; Boston, Brill, 2015, pp. 85-100. (Impact of Empire: Roman Empire, c. 200 BC-AD 476; vol. 20).

60. Litavrin G.G., Novoseltsev A.P. Kommentariy [Commentary]. Litavrin G.G., Novoseltsev A.P., eds. Konstantin Bagryanorodnyy. Ob upravlenii imperiey [Constantine Porphyrogennetos. On the Administration of the Empire]. Moscow, Nauka Publ., 1991, pp. 276-457.

61. Ljubić Š. O Posavskoj Hrvatskoj i o zlatnih novcih njezina zadnjega kneza Serma (1018) [On the Posavian Croatia and the gold coins of its last duke Sermo]. Rad Jugoslavenske akademije znanosti $i$ umjetnosti, 1878, vol. 43, pp. 107-148.

62. Lončar M. Filološka analiza Porfirogenetovih vijesti o Hrvatima: PhD diss [A Philological Analysis of Porphyrogennetos's Information about Croats]. Zadar, 2002.570p.

63. Lucius Ioannes. De regno Dalmatiae et Croatiae. Kuntić-Makvić B., Kurelac M., Budak N., Goldstein I., eds. Zagreb, VPA, 1986. 471 p., [5] fold. il. (Biblioteka Latina et Graeca; vol. 7).

64. Margetić L. Pitanja iz najstarije povijesti Zagrebačke biskupije i Slavonije [Questions about the earliest history of the Zagreb Bishopric and Slavonia]. Margetić L. Zagreb i Slavonija. Izbor studija. Zagreb, Hrvatska akademija znanosti i umjetnosti; Rijeka, Vitagraf, Adamicě, 2000, pp. 33-83.

65. Margetić L. Još o pitanju vremena dolaska Hrvata [Some more about the question concerning the arrival of Croats]. Margetić L. Dolazak Hrvata. Split, Divič, 2001, pp. 137-148.

66. Margetić L. Još o vijestima Konstantina Porfirogeneta o dolaska Hrvata [Some more about Constantine Porphyrogennetos's information about the arrival of Croats]. Margetić L. Dolazak Hrvata. Split, Divič, 2001, pp. 155-170.

67. Margetić L. Konstantin Porfirogenet i vrijeme dolaska Hrvata [Constantine Porphyregennetos and the time of the arrival of Croats]. Margetić L. Dolazak Hrvata. Split, Divič, 2001, pp. 41-113.

68. Matijević-Sokol M., Sokol V. Hrvatska i Nin u doba kneza Branimira [Croatia and Nin in the time of prince Branimir]. Zagreb, Hrvatski Studiji Sveučilišta u Zagrebu, 2005. $114 \mathrm{p}$.

69. Menander Protector. Historia. Blockley R.C., ed. The History of Menander the Guardsman. Liverpool, F. Cairns, 1985. 307 p. (ARCAClassical and Medieval Texts, Papers and Monographs; vol. 7).

70. Mihajlović V.P. Imagining the Ister/Danube in Ancient Thought and Practice: River, the Scordisci, and Creation of Roman Imperialistic Space. Etnoantropološki problemi, n.s., 2018, vol. 13 (3), pp. 747-780.

71. Németh A. The Excerpta Constantiniana and the Byzantine Appropriation of the Past. Cambridge, Cambridge Univ. Pr., 2018. xiv, 338 p.

72. Notitia dignitatum. Neira Faleira C., ed. La Notitia dignitatum. Nueva edición crítica y comentario histórico. Madrid, Consejo Superior de Investigaciones Cientiěficas, 2005. 697 p. (Nueva Roma; vol. 25).

73. Pohl W. Ethnicity, Theory, and Tradition: A Response. Gillet A., ed. On Barbarian Identity. Critical Approaches to Ethnicity in the Early Middle Ages. Turnhout, Brepols, 2002, pp. 221-239.

74. Procopius Caesariensis. Opera omnia. Vol. I: De bellis libri I-IV. Vol. II: De bellis libri V-VIII. Haury J., Wirth G, eds. Leipzig, In aedibus B.G. Teubneri, 1962 $1963.572+699$ p. (repr. Berlin-New York, De Gruyter, 2013).

75. Radić M. Dva ulomka kamene plastike XI. st. iz Baranje u Muzeju Slavonije u Osijeku [Two fragments of the 11th-century stone sculpture from Baranya in the Museum of Slavonia in Osijek]. Osječki zbornik, 1993/1995, vol. 22/23, pp. 99-122.

76. Šafárik P.J. Slawische Altertümer. Vol. II. Leipzig, W. Engelmann, 1844. xiv, 742 p.

77. Ševčenko I. Re-reading Constantine Porphyrogenitus. Shepard J., Franklin S., eds. Byzantine Diplomacy. Aldershot, Variorum, 1995, pp. 167-195.

78. Shepard J. Soldiers, missionaries and diplomacy under Gibbon's eyes. McKitterick R., Quinault R., eds. Edward Gibbon and Empire. Rev. ed. Cambridge, Cambridge Univ. Pr., 2002, pp. 78-100.

79. Šišić F. Povijest Hrvata u vrijeme narodnih vladara [The History of the Croats in the time of the national rulers]. Zagreb, Nakladni zavod Matice hrvatske, 1925 (repr. 1990). xvi, 749 p.

80. Šlaus M. Kraniometrijska analiza srednjovjekovnih populacija središnje Europe s posebnim osvrtom na položaj hrvatskih lokaliteta [Craniometric analysis of the medieval Central European populations with special regard to the status 
of the Croatian sites]. Starohrvatska prosvjeta, 1998, vol. 25, pp. 81-107.

81. Šlaus M. Kraniometrijska analiza srednjovjekovnih nalazišta središnje Europe: novi dokazi o ekspanziji hrvatskih populacija tijekom 10. do 13. stoljeća [Craniometric analysis of the medieval Central European sites: new evidence of the expansion of the Croatian populations in the $10^{\text {th }}$ to $13^{\text {th }}$ century]. Opuscula archaeologica, 1999/2000, vol. 23-24, pp. 273-284.

82. Šlaus M. Bioarheologija. Demografija, zdravlje, traume $i$ prehrana starohrvatskih populacija [Bioarcheology. Demography, health, traumata and nourishment of the old Croatian populations]. Zagreb, Školska knjiga, 2006. 254 p.

83. Šlaus M., Tomičić Ž., Uglešić A., Jurić. R., eds. Craniometric relationships among medieval Central European populations: Implications for Croat migration and expansion. Croatian Medical Journal, 2004, vol. 45 , pp. $434-444$.

84. Smičiklas T. Poviest hrvatska. Vol. I: Od najstarijih vremena do godine 1526 [The Croatian History I: from the earliest times until the year 1526]. Zagreb, Matice Hrvatske, 1882. xxxii, 724 p.

85. Sokol V. Panonija i Hrvati u 9. stoljeću [Pannonia and the Croats in the 9th century]. MajnarićPandžić N., ed. Arheološka istraživanja u Podravini i kalničko-bilogorskoj regiji. Znanstveni skup Koprivnica, 14-17. X. 1986. Zagreb, Hrvatsko Arheološko Društvo, 1990, pp. 193-195. (Izdanja Hrvatskog arheološkog društva; vol. 14).
86. Sokol V. Arheološka baština i zlatarstvo [Archaeological heritage and gold artifacts]. Supičić I., ed. Hrvatska i Europa. Kultura, znanost i umjetnost. I: Srednji vijek (VII-XII. stoljeće). Rano doba hrvatske kulture. Zagreb, AGM, 1997, pp. 117-146.

87. Sokol V. Medieval Jewelry and Burial Assemblages in Croatia. A Study of Graves and Grave Goods, ca. 800 to ca. 1450. Leiden; Boston, Brill, 2016. 256 p. (East Central and Eastern Europe in the Middle Ages, 450-1450; vol. 36).

88. Suić M. Ocjena radnje L. Margetića “Konstantin Porfirogenet i vrijeme dolaska Hrvata" [An Appraisal of L. Margetić's paper 'Constantine Porphyregennetos and the Time of the Arrival of Croats']. Zbornik Odsjeka za povijesne znanosti Zavoda za povijesne $i$ društvene znanosti Hrvatske akademije znanosti i umjetnosti, 1977, vol. 8, pp. 89-100.

89. Theophanis Chronographia. Vol. I. De Boor C., ed. Leipzig, In aedibus B.G. Teubneri, 1883. viii, 503 p.

90. Thomae Archidiaconi Spalatensis Historia Salonitanorum atque Spalatinorum pontificum. Perić O., Karbić D., Matijević-Sokol M., Sweeney J.R., eds. Budapest; New York, Central European Univ. Pr., 2006. xliv, 404 p. (Central European Medieval Texts; vol. 4).

91. Wolfram H. Salzburg, Bayern, Österreich. Die Conversio Bagoariorum et Carantanorum und die Quellen ihrer Zeit. Vienna; Munich, R. Oldenbourg Verl., 1995. $464 \mathrm{p}$.

92. Zeuss K. Die Deutschen und die Nachbarstämme. Munich, Lentner, 1837. viii, 778 p.

\section{Information About the Author}

Hrvoje Gračanin, PhD, Full Professor, Department of History, Faculty of Humanities and Social Sciences, University of Zagreb, Ivana Lučića, 3, 10000 Zagreb, Croatia, hgracani@ffzg.hr, https://orcid.org/0000-0001-5018-6083

\section{Информация об авторе}

Хрвое Грачанин, PhD, профессор кафедры истории философского факультета, Загребский университет, ул. Ивана Лучича, 3, 10000 г. Загреб, Хорватия, hgracani@ffzg.hr, https://orcid.org/0000-0001-5018-6083 